Hans-Peder Kromann

\title{
Base b11: FAGSPROGSBIBLIOGRAFIEN
}

\author{
Sprogbiblioteket, HERMES on-line katalog, Handels- \\ højskolen i København
}

En fyldig bibliografi er et nyttigt redskab også for fagsprogsforskere, som skal kende deres områdes "State of Art" eller "Forschungsstand", hvis de vil knytte an til international fagsprogsforskning inden for deres forskningsfelt. Den bibliografi, som præsenteres her, ligger på HHK i Sprogbibliotekets database. Vi håber, den kan bidrage til, at der slås bro over kløfterne mellem de forskellige fag og sprog, og at lingvister og fagsprogsfolk finder nogle flere fælles forskningsområder. I denne bibliografi er det sproglige element i fagsproget prioriteret højere end selve faget i fagsproget. Man kan altså søge litteraturhenvisninger til beskrivelser af økonomisk, juridisk eller teknisk sprog, men ikke henvisninger til litteratur om økonomi, jura eller teknik.

Denne fagsprogsbibliografi er baseret på H.K. Mikkelsen/H.-P. Kromann: Fagsprog og fagsproglig kommunikation ca. 1970 - 1988. En udførlig systematisk bibliografi på database, som er udarbejdet med støtte fra Statens Humanistiske Forskningsråd under Initiativområdet "Fagsprog og fagsproglig kommunikation". Projektet er beskrevet i 2 tidligere artikler i Hermes 1 (1988) og Hermes 2 (1989).

Sprogbibliotekets HERMES-database indeholder i base b11 over 10.000 litteraturhenvisninger omhandlende fagsprog, især publikationer fra perioden 1970 til i dag. Man kan søge litteratur om emner som fagintern eller -ekstern kommunikation, tekstlingvistik, grammatik, leksikologi, terminologi, oversættelse, pædagogik, korpora, m.v., først og fremmest inden for følgende sprog: dansk (104), engelsk (2053), fransk (912), italiensk (26), russisk (3142), spansk (78) og tysk (2620). Tallene i parentes angiver antallet af litteraturreferencer til sprogene som genstandssprog. Ligesom i HERMES-basen hhb kan man søge på forfatternavne, emner, udgivelsesår, ord i titel m.v. De personlige søgeresultater kan udprintes og tages med hjem.

Den vigtigste indgang til litteratursøgningen er nedenstående klassifikationstal med em = ..., som udgør fagsprogsbibliografiens egen systematik. Den er baseret på det sprogsyn, at sprogforskning sædvanligvis 
foregår på et eller flere af følgende forskellige beskrivelsesniveauer: kommunikation, tekst, sætning, ord eller oversættelse. NB! Disse klassifikationstal har intet med UDK-klassifikationen at gøre!

\section{Klassifikationstallene til databasens emneområder}

I parentes er anført antallet af litteraturreferencer til hvert em

1 Bibliograferede værker $\mathrm{em}=1(226)$

2 Forskningsoversigter og -programmer $\mathrm{em}=2(232)$

\section{Diakron fagsprogsforskning (fagsprogshistorie)} $\mathrm{em}=3(534)$

4 Forskning i fagsprog og fagsproglig kommunikation $\mathrm{em}=41(656)$

Almensprog, fagsprog og funktionalstile (generelle problemstillinger) samt almen metodelære

$\mathrm{em}=42(527)$

Fagekstern kommunikation, herunder sprogkritik, sprogkonflikter ( $\mathrm{fx}$ forvaltning og administration, populærvidenskab, publicistik og journalistik, reklame, information, public relations)

$\mathrm{em}=43(346)$

Fagintern kommunikation (vertikalt perspektiv)

$\mathrm{em}=44$ (449)

Almene beskrivelser af udvalgte fagområders sprogbrug (horisontalt perspektiv, med særlig vægt på samfundsvidenskaberne politik, økonomi og jura samt matematik/naturvidenskab og anvendt videnskab, medicin, teknik, sport, religion)

\section{Fagsproglig tekstbeskrivelse og grammatik (tekstlingvistik, pragmatik)}

$\mathrm{em}=51(667)$

Tekstklassifikation, teksttyper og -arter, herunder kommunikationstyper m.v.

$\mathrm{em}=52$ (344)

Tekstens makro- og mikrostrukturer (retorik, stilistik, 
kohærens, kohæsion, konnektorer, tema-rema, metaforer, talehandlinger)

$\mathrm{em}=53(703)$

Grammatik (morfologi og syntaks, fx valens, nominalisering, diatese, modalitet). Fonetik og udtale

\section{Det fagsproglige ordforråd}

$\mathrm{em}=61(762)$

Almene værker om fagsprogsleksik (fagsproglig leksikologi, terminologilære, problemer og principper, metodelære, navne)

$\mathrm{em}=62$ (371)

Orddannelse, herunder låneord, neologi, forkortelser $\mathrm{em}=63(260)$

Ordforbindelser, flerordstermini, ordgruppeleksemer, fraseologismer, kollokationer

$\mathrm{em}=64$ (209)

Standardisering (normering), sprogplanlægning og nomenklaturlære (national og international)

$\mathrm{em}=65$ (407)

Fremstilling af etsprogede fagordbøger, terminografi, encyklopædier o.l.

$\mathrm{em}=66(759)$

Fagspecifik terminologi med særlig vægt på samfundsvidenskaberne politik, økonomi og jura samt matematik/naturvidenskab og anvendt videnskab, medicin, teknik, sport, religion

\section{Fagsproglig kommunikation mellem to eller flere sprog} (interlingval kommunikation)

$\mathrm{em}=71(659)$

Almene værker om oversættelsesteori, fagsproglig oversættelse og interkulturel kommunikation $\mathrm{em}=72(332)$

Leksikalske og terminologiske oversættelsesproblemer (kontrastiv leksikologi, komparativ terminologi) $\mathrm{em}=73(92)$

Kulturelt og ideologisk konnoteret leksik (lingvorealia) 
$\mathrm{em}=74(240)$

Principper for oversættelsesleksikografi (bi- og multilingvale ordbøger, alfabetiske og systematiske ordbøger) $\mathrm{em}=75(173)$

Grammatiske og tekstlingvistiske oversættelsesproblemer

\section{Fagsproglig didaktik og pædagogik}

$$
\mathrm{em}=8(746)
$$

\section{Fagsproglige korpora (beskrivelse og udnyttelse)}

$$
\mathrm{em}=9 \text { (89) }
$$

I nogle tilfælde har litteraturreferencer kunnet få et UDK-tal, men det er altså kun i begrænset omfang, man kan søge på følgende UDK-tal i fagsprogsbibliografien. I parentes er anført antallet af litteraturreferencer til hvert kl:

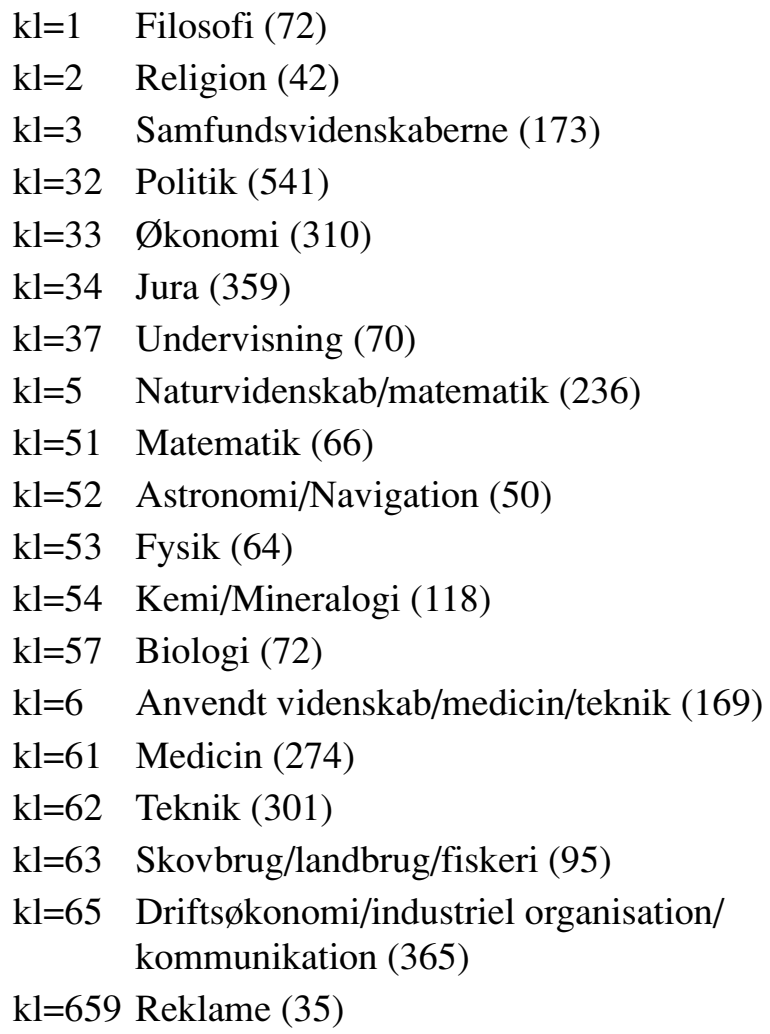


$\mathrm{kl}=69 \quad$ Byggeri $(28)$

$\mathrm{kl}=7 \quad$ Kunst/idræt (304)

$\mathrm{kl}=72$ Arkitektur (15)

$\mathrm{kl}=78$ Musik (18)

$\mathrm{kl}=79$ Idræt/underholdning (85)

$\mathrm{kl}=91 \quad$ Geografi $(25)$

$\mathrm{kl}=93$ Historie (19)

\section{Praktisk eksempel på søgning}

Hvad kan databasen så bruges til? Den kan f.eks. svare på: Hvilke referencer er der i databasen til publikationer om orddannelse $i$ engelsk fagsprog? I parentes er anført antallet af fundne litteraturreferencer. Da vi skal bruge oplysninger om orddannelse i engelsk fagsprog, indtastes der:

$$
\text { em=62 og engelsk (91) }
$$

Hvis man synes, at det er for mange litteraturhenvisninger, kan man præcisere søgningen yderligere ved at tilføje en årrække, man ønsker at søge på. Der indtastes fx:

$$
\text { em=62 og engelsk og år=1980 til } 1990 \text { (53) }
$$

Referencerne vil herefter komme frem på skærmen.

Ved hjælp af UDK-tallene har man mulighed for at begrænse sin søgning til et af fagsprogene, fortrinsvis: фkonomi, jura, teknik og politik. Søgningen sker da ved hjælp af de ovenfor anførte UDK-tal, men det er som antydet problematisk, idet et stort antal referencer ikke på meningsfuld måde kan tildeles et UDK-tal. Ovenstående eksempel kan præciseres ved hjælp af UDK-klassifikationstallet for teknik.

em=62 og engelsk og år=1980 til 1990 og kl=62

\section{Eksempler på andre søgemuligheder}

$$
\text { em=71 og fransk (86) }
$$

dvs. oversættelse af fransk fagsprog

$$
\mathrm{em}=53 \text { og tysk og kl=62 (9) }
$$

dvs. grammatik i tysk teknisk sprog 
108

econom? (31)

dvs. en trunkering, hvorefter der søges på ordene econom-y, -ics, économique o.l. i databasens titler.

Ikke uventet er databasen behæftet med enkelte fejl og mangler, men de vil blive søgt korrigeret. Databasen er blevet ajourført siden 1989 og søges løbende opdateret med nye litteraturreferencer fra udkommende tidsskrifter og samleværker.

Interesserede fagsprogsforskere kan få yderligere oplysninger hos denne artikels forfatter. 